\title{
SUBSTITUTION VALUE OF A MIXTURE OF RICE MILLING BY-PRODUCTS FOR MAIZE IN DIETS OF WEANER RABBITS.
}

\author{
B.O. ESONU \\ Department of Animal Production, Federal University of Technology, P.M.B. 1526, Owemi, \\ Nigeria
}

Received 31 July 1996; Accepted 23 June, 1997

\begin{abstract}
A 12 - week feeding trial involving 64 weaner rabbits in a completely randomized design was carried out to determine the substitution value of a mixture of rice milling by-products (in the ratio of 1:1:1:2 respectively for straw, husk, hull, and bran) for maize in the diets of New Zealand white type weaner rabbits at four substitution levels: $\mathbf{0 \%}, \mathbf{5 0 \%}$, $75 \%$ and $100 \%$. Rabbits on the experimental diets recorded higher feed intake of $\mathbf{6 8 . 8 3}$, 68.11 and $66.97 \mathrm{gm}$ respectively for $50 \%, 75 \%$ and $100 \%$ as against $52.71 \mathrm{gm}$ for $0 \%$. The difference in feed intake between the group on $0 \%$ and the group on experimental diets became significant $(\mathrm{P}<0.05)$ at $50 \%$ dietary substitution level, but there was no significant $(P>0.05)$ difference among the group on the experimental diets. Rabbits on $50 \%$ substitution level recorded the highest feed intake $(68.83 \mathrm{gm})$ while the group on $100 \%$ recorded the highest feed conversion ratio (15.72). Body weight gain of the groups showed significant difference $(P<0.05)$. The mixture of rice milling by-products used for this study contained $9.10 \%$ crude protein, $30.4 \%$ crude fibre, $0.29 \%$ calcium, $0.19 \%$ phosphorus and $2.01 \mathrm{kcal} / \mathrm{kg}$ metabolizable energy levels. The results of this trial suggest that a mixture of rice milling by-products could substitute maize in weaner rabbits diets up to $50 \%$ with good results.
\end{abstract}

Keywords: rice, by-products, maize substitute, weaners, Rabbits.

\section{INTRODUCTION}

Mixture of rice milling by-products comprised a ratio of 1:1:1:2 of rice straw, hull, husk and bran mixed together. Until recently, little was heard about this mixture (Ekpenyong, 1986). Most researchers have dealt extensively on the bran (Gillespie, 1981; Briggs, 1978; McDonald et al, 1981) while the husk and straw have been used mainly in providing litter materials for livestock (Reddish et al, 1986). The recent trend in the price of conventional feedstuffs and the non-availability of such feedstuffs have aggravated the problems facing the animal production sector in bridging the yawning protein gap in developing countries. Moreso, maize and other feed grains remain staple food for most developing countries resulting in keen zompetition between man and livestock (Onwrdike and Omole, 1994; Ngodigha, 1993, Esonu et al, 1994, 1996). There is thereforc urgent need for a substitute for maize that is localy available, cheap, attracting no competition with man and requires no or minimal, processing cost to make it utilizable.

A mixture of rice milling by-products at the ratio of 1:1:1:2 of rice straw, hull, husk and bran mixed together is locally available in large quantities, cheap and utilizable without much processing (Oyenuga, 1968; Jackson, 1978; Aduku et al, 1986, Ekpenyong, 1986). The aim of this study is therefore to evaluate the substitution value of a mixture of rice milling by- products for maize in weaner rabbit diets.

\section{MATERIALS AND METHODS}

The mixture of rice milling by-products used for this study was obtained from Ikpe Rice Mill Processing Unit located at Ini local government area of Akwa Ibom State of Nigeria. The milling process consisted of the removal of the straw, husk, hull and bran by a mechanical separator. These by-products were mixed together in the ratio of 1:1:1:2 of straw, husk, hull and bran and ground in a hammer mill, "producing a finely ground mixture of rice mill by-products. Molasses was used as a binder to pellet both the rice mill 
TABLE 1: CHEMICAL COMPOSITION OF A MIXTURE OF RICE MILLING BY- PRODUCTS AND MAIZE (Dry Matter basis)

\begin{tabular}{lll}
\hline Parameters & $\begin{array}{l}\text { Mixture of Rice } \\
\text { mill by-products }\end{array}$ & Maize \\
\hline Dry matter (\%) & 91.00 & 89.00 \\
Crude protein (\%) & 9.10 & 8.80 \\
Crude fibre (\%) & 30.40 & 2.20 \\
Crude fat (\%) & 1.90 & 4.60 \\
Calcium (\%) & 0.29 & 0.28 \\
Phosphorus (\%) & 0.19 & 0.17 \\
${ }^{*}$ Lysine (\%) & 0.50 & 0.24 \\
${ }^{*}$ Methionine + & & \\
Cystine (\%) & 0.17 & 0.21 \\
${ }^{*}$ Metabolizable & & 3.33 \\
energy (kcal/gm) & 2.01 & \\
\hline "Calculated. & &
\end{tabular}

assigned to the four treatment diets at 16 rabbits per treatment. Each treatmen was further replicated four times and each replicate group of 4 rabbits housed in a hutch of $180 \times 60 \mathrm{~cm}$. Dry matter of the mixture of rice by-products and the diets was determined by oven drying and crude protein by the macro Kelahl procedure (AOAC, 1980). Mineral analysis was made by methods of Grueling (1966). Metabolizable Energy (ME) was calculated based on documented ME values of materials used.

Data collected were subjected to analysis of variance as outlined by Snedecor and Cochran (1974). When analysis of variance indicated a significance for treatment effects, specific differences between means were detected using the modified Duncan New multiple

\section{TABLE 2: COMPOSITION OF THE TREATMENT DIETS FED TO RABBITS}

\begin{tabular}{lllll} 
Ingredients & \multicolumn{4}{c}{ Substitution level of the mixture (\%) } \\
\hline Maize & $\mathbf{0}$ & $\mathbf{5 0}$ & $\mathbf{7 5}$ & $\mathbf{1 0 0}$ \\
Mixture of rice milling by-products & 60.00 & 30.00 & 15.00 & 0.00 \\
Soya bean meal & 0.00 & 30.00 & 45.00 & 60.00 \\
Fish meal & 31.00 & 31.00 & 31.00 & 31.00 \\
Bone meal & 4.00 & 4.00 & 4.00 & 4.00 \\
Blood meal & 2.50 & 2.50 & 2.50 & 2.50 \\
Salt & 2.00 & 2.00 & 2.00 & 2.00 \\
Pfizer vit/Tm premix* & 0.25 & 0.25 & 0.25 & 0.25 \\
Total & 0.25 & 0.25 & 0.25 & 0.25 \\
\hline${ }^{*}$ To provide the follown & $\mathbf{1 0 0 . 0 0}$ & $\mathbf{1 0 0 . 0 0}$ & $\mathbf{1 0 0 . 0 0}$ & $\mathbf{1 0 0 . 0 0}$ \\
\hline
\end{tabular}

* To provide the following per $\mathrm{kg}$ of feed:

Vitamin A - 10,000,000 I.U. D3-2,000.00 I.U.; B - 0.75g; B12 - 5g; Nicotinic acid - 25g; Calcium panthotenate - $12.5 \mathrm{~g} \mathrm{B12-}$ $0.015 \mathrm{~g}$; K3-2.5g; E-25g; Biotin 0.05g; Folic acid - 1g; Cholice chloride $250 \mathrm{~g}$; Cobalt - 0.40g; Copper 8g; Manganese - 64g; Iron - 32g; Zinc-40g; Iodine - 0.8g; Flavomycin - 100g; Spiramycin-5g; 3-Nitro-5g; DI-Methionine 50g; Selenium 0.16;

by-products-based diets and the maize-based diet (equal quantity of molasses was used (5 litres) per $25 \mathrm{~kg}$.

Samples of the mixture and maize were analysed for proximate chemical composition (AOAC, 1980), Table 1.]. Based on the result of the chemical analysis, four weaner rabbit experimental diets were formulated such that the mixture of rice mill by- products substituted maize at $0 \%, 50 \%, 75 \%$ and $100 \%$ levels (Table 2).

Sixty-four, five-week-old weaner rabbits of New Zealand white type were randomly range (1955) as outlined by Obi (1990). The experiment lasted for 12 weeks.

\section{RESULTS AND DISCUSSION}

The chemical compusition of the treatment diets is presented in Table 3. The mixture and maize appeared comparable in most of the nutrients (Table 1) and substitution was done on weight for weight basis. The only major observable differences among the treatment diets were the decrease in metabolizable energy of the diets as the level of the mixture of rice milling by-product increased and the 
RICE MILLING BY-PRODUCTS FOR RABBITS

TABLE 3: CHEMICAL COMPOSITION efficiency of feed conversion. Rabbits on $50 \%$

OF THE TREATMENT DIETS FED TO THE WEANER RABBITS.

\begin{tabular}{lllll}
\hline Paramelers & \multicolumn{2}{l}{ Substitution } & Levels & $(\%)$ \\
& $\mathbf{0}$ & $\mathbf{5 0}$ & $\mathbf{7 5}$ & $\mathbf{1 0 0}$ \\
\hline Crude protein & 21.6 & 22.00 & 22.15 & 22.40 \\
Ether extract & 4.09 & 3.00 & 2.50 & 2.03 \\
Crude fibre & 3.37 & 9.37 & 12.87 & 17.37 \\
Available calcium & 0.34 & 0.36 & 0.38 & 0.39 \\
Phosphorus & 0.26 & 0.28 & 0.29 & 0.29 \\
*ysine & 1.22 & 1.20 & 1.19 & 1.14 \\
*Methionie + & & & & \\
cystine & 0.64 & 0.66 & 0.69 & 0.71 \\
*Metabolizable & & & & \\
energy (Kcal/kg) & 2230.0 & 2160.0 & $20 \% 4.0$ & 1990.5 \\
Calorie/protein & & & & \\
ratio & 0.11 & 0.11 & 0.10 & 0.10 \\
\hline
\end{tabular}

* Calculated.

TABLE 4: THE EFFECT OF MIXTURE OF RICE MILLING. BY-PRODUCTS ON THE PERFORMANCE OF WEANER RABBITS.

\begin{tabular}{|c|c|c|c|c|c|c|}
\hline \multirow{2}{*}{ Parameters } & \multicolumn{3}{|c|}{ Sulostitution } & \multicolumn{2}{|c|}{ leveis $(\%)$} & \\
\hline & 0 & 50 & 75 & 100 & $\mathrm{SI}: \mathrm{M}$ & \\
\hline Initial body weight $(\mathrm{g})$ & 6.59 .25 & 6.59 .25 & 6.59 .35 & 6.59 .25 & 0.0112 & \\
\hline Final body weight (g) & 985.250 & $1166.25 \mathrm{a}$ & $10(11.251)$ & 557.2513 & 2.34 & \\
\hline Body weight changes (g) & $326,(x) h$ & $407.0)(1 \mathrm{a}$ & $342 .(1)(\mathrm{H})$ & $29)(x+1)$ & 4.48 & $\cdot \cdot$ \\
\hline Daily feed intake (g) & $52.71 \mathrm{~d}$ & $68.8 .3 \mathrm{~b}$ & (88.1 ib & $66.97 \mathrm{~b}$ & 0.2 .3 & \\
\hline Daily body weight gain (g) & $4.6(16)$ & 5.81 & 4.8913 & $4.2(3)$ & 1.25 & \\
\hline \multicolumn{7}{|l|}{ Feed conversion ratios } \\
\hline (kg, feed/kg gain) & $11.31 \mathrm{a}$ & 13.84 í & 1.3.92h & $15.72 \mathrm{~b}$ & 4.115 & \\
\hline Feed cost $(\mathrm{A} / \mathrm{kg})$ & 15.5 & 14.11 & 1.3 .11 & 12.6 & & \\
\hline $\mathrm{H} / \mathrm{kg}$ meat produced & 62.21 & $47.3 f$ & 41.7 & $41\} .87$ & & \\
\hline Mortality & 0 & 11 & 11 & () & & \\
\hline
\end{tabular}
$a, b \cdot$ means within sows with different superscripts are statistically different $(P<0.0 .5)$.

increase in the crude fibre contents of the diets as the dietary level of the mixture of rice milling by- product increased. This was understandably so because of the low energy value and the high crude fibre contents of the mixture of rice milling by-products.

Data on feed intake, body weight changes and feed conversion ratio are presented in Table 4. There was significant $(P<0.05)$ difference in feed intake between the $0 \%$ and experimental diets. The mixture of rice milling by-products at $50 \%$ substitution level significantly $(P<0.05)$ improved the growth rate of the rabbits, an indication of higher mixture of rice mill by-products substitution level generally performed better than those on $0 \%$ level. $(P>0.05)$. The poor performance of rabbits on $75 \%$ and $100 \%$ could be probably due to the low energy content of these diets and the high dictary level of the mixture which may have affected nutrient digestihility and utilization (Onwudike and Omole, 1\%4). Based on the results of the chemical analyses (Table 1), the mixture of rice milling by-products contained the necessary nutrients at comparatively high levels despite the fact that it was low in methionine.

It is interesting to note that with the unique caccotrophic habit of the rabbit which places the animal at advantage in the utilization of 
cost could be reduced by as much as $9.7 \%$.

In conclusion, the result of this trial showed that the mixture of rice mill by-product at a ratio of 1:1:1:2 of rice straw, husk and bran could be substituted for maize at $50 \%$ level in weaner rabbit diets with -. improved performance.

\section{REFERENCES}

ADUKU, A.O.; OKOH, P.N.; NJOKU, P.C.; AGANGA, A.A. AND DIM, N.I. (1986); Evaluation of cowpea (Vigna unguiculata) and pea nut (Arachis hypogaea) haulms as feedstuffs for weanling rabbits in a tropical environment (Nigeria). Journal of Applied Rabbit Research 9(4): 178-180

ASSOCIATION, OF OFFICIAL ANALYTICAL CHEMISTS (1980). Official Methods of Analysis, 13th ed. Washington. D.C. BRIGGS, F.A. (1978): Rice mills as substitute for wheat straw in sheep feeding. Alexandria Journal of Agriculture Reseach, xiii: 1 - 10.

CHEEKE, P.R; GROBNER, M.A. AND PATTON, N.M. (1986) Fibre Digestion and Utilization in rabbits. The Journal of Applied Rabbits Research. 9(1): 25 - 30

DUNCAN, D.B. (1955): Multiple range and multiple F - tests, Biom. 11: 1 - 42.

EKPENYONG, T.E. (1986) Nutrient Composition of tropical feedstuffs available for rabbits feeding. J. Appl. Rabbit Research 9. (3) 100-102.

ESONU, B.O.; UDEDIBIE, A.B.I.; HERBERT, U. AND ODEY, J.O. (1996). Comparative evaluation of raw and cooked jackbean (Canavalia ensifonnis) on the performance of weaner rabbits $J$. World Rabbit Science. 4 (3) 139 - 141.

ESONU, B.O; UZOMA, R.A. AND EGENUKA, S.A. (1994) Evaluation of graded levels of dried poultry Waste in
Weaner Rabbits diet. Journal of Science and Technology (in press) Vol. $2 / 3$.

GILLESPIE, R. (1981). Modern Livestock and Poultry Production. Delma Publisher, New York.

(iRUELING, H.T. 91966). The chemical analysis of plant tissues. Mimeo no 6622. Agronomy dept. Cornel University, Ithaca, N.Y.

JACKSON, M.G. (1978): Treating straw for Animal Feeding, F.A.O. Animal production and Health paper No. 10.

MCDONALD, P. EDWARDS, R.A. AND GREENHALGH, J.F.D. (1981). Animal Nutrition. 3rd edition. Longman Group Ltd. UK. P. 406.

NGODIGHA, E.M. (1993): Garri sievate incal in diets of Rabbits, Paper presented at the 18 th annual conf. of NSAP held in Owerri21st - 25th March.

OBI, I.U. (1990): Statistical methods of Detecting Differences betwcen Treatment Means. Snaap press, Enugu, Nigeria. 2nd edition.

ONWUDIKE, O.C. AND OMOLE, T.A. (1994). The use of maize cob in Rabbit diets. Paper presented at the 19 th annual conf. of NSAP held in Benin 20th - 23rd March.

OYENUGA, V.A. (1968). Nigeria's foods and feeding-stuff 3 rd edition. Ibadan University Press.

REDDISH, P.M. AND SEARR, M.J. (1986): Subsidiary Industries for livestock sector. Paper presented at the 11th annual conf. NSAP, A.B.U. Zaria, Nigeria.

SNEDECOR, G.W. AND COCHRAN, W.G. (1974) Statistical Methods, The IOWA State University Press, Ames. IOWA. 6th ed. 